\title{
Rudolf Steiner as a Religious Authority
}

he aim of this paper is to clarify what Rudolf Steiner's followers
thought of him at the time of his demise. Rudolf Steiner (1861-1925) was the founder of one of the more established new religious movements, the Anthroposophical Society. In 1903, Steiner was elected Secretary General for the Berlin section of the Theosophical Society. However, he left the Theosophical Society in 1913 and founded the Anthroposophical Society, which he reorganised in 1924. In 1922, he founded the Christian Community, which is not formally part of the Anthroposophical Society, but it is doctrinally based on Steiner's so-called revelations.

How can we explain the rapid spread of the Anthroposophical Society in Europe and the United States during the inter-war period? Can it be explained by referring to Rudolf Steiner's own authority? What kind of authority did he possess? Did the members of the Anthroposophical Society regard him as a divine being, a prophet, or an ordinary religious teacher? An answer to this question is required in order to understand the emergence and development of the Anthroposophical Society-and so far, the question has not been answered from the stance of comparative religion.

The material for my present paper consists of a selection of the obituaries published in the anthroposophical press after Rudolf Steiner's death on 30 March 1925. Needless to say, obituaries are usually tendentious, and therefore controversial as source material. For my purpose, however, this kind of material is suitable, since I explicitly aim to study the tendency itself. The restraint that followers might be assumed to practice in publishing their opinion on Steiner in commonly available writings is minimised in the type of material chosen here. My primary interest is to find out whether his followers portray Steiner as a human being, or as a divine, or semi-divine being. 


\section{Spiritual Leader}

In several contexts, Steiner is called 'spiritual leader' or 'Führer'. This does not usually refer to Steiner as leader of the Anthroposophists, but as leader of all of humankind - he is a 'Menschheitsführer', even a 'göttlicher Mensschheitsführer' (Steffen 1925a: 105, 1925b: 147; Karutz 1925a: 157; Uehli 1925: 180; Spörri 1925: 54). As a spiritual leader of humanity, Steiner is ascribed a religious, not a political task: 'Soon the day will come when people are going to recognise and praise him [Steiner] as their saviour and leader in a time of great spiritual distress' (Karutz 1925b: 166). But Steiner is also a spiritual leader for individuals; he is 'our faithful friend and spiritual leader, a spiritual leader and philanthropist with endless love and humbleness' (Reinhart 1925: 125; Picht 1925: 221).

The Christian Community places Steiner in the Christian history of salvation by describing him as 'ein Führer zu Christus' (Beckh 1925: 45). His task as 'a leader in our time' is legitimated by a 'spiritual authority'. Within the Christian Community also, Steiner was a leader for individuals: young people inwardly called upon Steiner as their leader. He represented an ideal according to which an inherently benevolent power can keep human weakness under control (Spörri 1925: 53).

\section{Teacher}

Besides the description of Steiner as spiritual leader, the epithet 'teacher' is also used. The function as teacher is entirely connected to his followers. Steiner is called 'our venerable teacher' and 'our beloved teacher' (Steffen 1925c: 113-14; Steffen 1925d: 122). 'The respected teacher, who gave his life for us by sacrificing himself for the holy work', was related to his future followers already before meeting them: 'It was predetermined that they were to encounter their teacher Steiner.' (Steffen 1925d: 122; Karutz 1925b: 165.) Within the Christian Community, Steiner's role as teacher of theologians is emphasized: the theologians chose him as teacher since he had divine authority (Spörri 1925: 55). 


\section{Founder of the Anthroposophical Society and the Christian Community}

Steiner's life's work was the founding of the Anthroposophical movement and the Christian Community, including the doctrines that these are based on.

On the whole, Steiner's written work is depicted as quite remarkable: Steiner's 'hand has written the deepest and the highest things about human fate' (Steffen 1925c: 113). In Steiner's numerous writings there are no contradictions and no errors: Steiner never contradicted himself in his plentiful lectures on various subjects and nobody has been able to prove a true error in the hundred books Steiner wrote. Therefore Steiner never needed to correct or improve his earlier writings; he simply supplemented them. (Rittelmeyer 1925: 37.) The thoughts presented in Steiner's writings originate from himself; he has not borrowed them from other writers or texts. It is wrong to say that Steiner has taken such and such ideas from India. He made all his discoveries himself (Rittelmeyer 1925: 36). This is also attested by Gertrud Spörri: 'Steiner has not borrowed from Gnosis, the Talmud or Indian and Persian scriptures' (Spörri 1925: 54). In reality, a high percentage of Steiner's anthroposophy consists of ideas borrowed from Helena Petrovna Blavatsky, who in turn had borrowed them from, among others, Gnosis, the Talmud, Indian and Persian scriptures.

According to Albert Steffen, Steiner's contribution provided his followers with the opportunity to adopt a religious view in a situation where most of them had already left their previous religion behind: 'Without his [Steiner's] spiritual work it would have been impossible for us to finally overcome Agnosticism . . . Steiner made available to us a religiosity, which stands above each sect and which depicts Protestantism and Catholicism in a higher light' (Steffen 1925d: 121). Within the Christian Community, Steiner is said to have conveyed a 'cult from the world of the living word' that is destined to become the 'modern expression for religious life and perception' (Beckh 1925: 49). Here, Steiner's role is, nevertheless, clearly subordinate to the role of Jesus: 'Christ is the only necessary helper of humanity, the great turning point in the history of humanity, a godly Messiah.' But man must save himself (Rittelmeyer 1925: 38), and to be able to do this, man needs to have access to Steiner's anthroposophy, which has emerged thanks to its creator's ability to convey 'messages from godly worlds' and brings gifts 'from the open heavens' (Steffen 1925d: 121; Spörri 1925: 
54; Rittelmeyer 1925: 40-1). However, a certain limitation characterises even Steiner: 'There were naturally many secrets that lay high above his spirit ... But godly secrets in an immense number were revealed to Steiner' (Rittelmeyer 1925: 40).

\section{Beholder of the Hidden}

Steiner's alleged ability to see into the hidden was the attribute that primarily separated him from other people. Steiner 'lived in a vision and he could talk with prophets and saints about their experiences as an equal' (Steffen 1925c: 114; Rittelmeyer 1925: 38, 41). This visionary ability is given as the explanation to his knowledge of things religious. Steiner could see into the invisible world. He 'dared construct a theory of knowledge on the angelic realm'. But there was nothing of Swedenborg here, nothing medial. It was a 'seeing with a clear intellect, but with higher organs'. (Rittelmeyer 1925: 40.) It was important for the Anthroposophists that Steiner should not be perceived as a medium, or a spiritist. Steiner's clairvoyant ability also explains why his doctrines include ideas found elsewhere, for example, in Gnosticism and NeoPlatonism. He has not borrowed the ideas from others, but they originate in the same source as the contents of Gnosticism or Neo-Platonism. Steiner took his ideas from the Akasha Chronicles, a universal memory which contains all that has happened since the beginning of the world. He could read the Akasha Chronicles and he conveyed more information from these chronicles than any other living person. (Rittelmeyer 1925: 37-40.) Steiner is also said to have had the ability to communicate with the spirits of the dead, which were present even when he lectured (Rittelmeyer 1925: 40).

\section{The Persecuted Steiner}

In his obituaries, Steiner is portrayed as a persecuted person: 'Steiner was pursued in life, humiliated and desecrated'; he 'was very misjudged and dishonoured'; 'Steiner was opposed'. One obituary claims that his persecution even took the form of 'a literary stoning of the dead Steiner'. (Reinhart 1925: 125; Karutz 1925a: 157; Krauss 1925: 166.) The reason given for the persecution of Steiner is that he was 'the new man' (Karutz 1925b: 165). 


\section{Scientist and Thinker}

The expressions for describing Steiner as a great scientist are manifold. Richard Karutz states the following: Steiner 'not only knew the most distant and special characteristics of all scientific disciplines, but he also introduced specialists to new problems, methods and knowledge within their areas'. Karutz, who himself was an ethnologist, assures his reader that he, thanks to Steiner, reached totally new insights in his own field (Karutz 1925b: 165). Steiner mastered all contemporary knowledge; he had a 'global education'. In him, knowledge and religion had become one. (Rittelmeyer 1925: 35; Frieling 1925: 58.)

\section{Summary}

It has emerged clearly above that Steiner was seen as the great spiritual leader, not only for individuals, but for all of mankind. He appears as a spiritual leader on the basis of a divine task, not because of his own divinity.

His followers also regard Steiner as a teacher. This function is totally uncontroversial. Steiner is the one who possesses knowledge and his followers receive it from him. It seems as if it is precisely his knowledge of hidden things, not Steiner himself, who attracts people to him.

Apart from being seen as a spiritual leader and teacher, Steiner is also described as the founder of a religion. He had given his followers a new faith that they could adopt in a situation where they had distanced themselves from Christianity. As preacher of this new faith-Spiritual Science-Steiner is perceived as being more or less infallible. Even if it seems that he has borrowed thoughts from other religious teachings, this is not the case. Using his clairvoyance, Steiner has himself learnt all that his faith includes.

His clairvoyant ability places Steiner on the same level as the greatest preachers of truth that humankind has known. His occult capability is not, however, explained by a god conveying the truth through him. He has come to know the truth by being able to see into the concealed-that is, read the Akasha Chronicles-thanks to his own practiced ability to use his spiritual senses. If somebody thinks he finds points originating in other religions and philosophies in the teachings of Steiner, he is mistaken; he re-sees these points in Steiner, who has taken them from the Akasha Chronicles, not from other religions or philosophies. 
Because of his interest in occult seeing, Rudolf Steiner reminds us of the great occultist C. W. Leadbeater, belonging to the society Steiner originated from, the Theosophical Society.

Steiner is attributed with the ability to communicate with the spirits of the dead-without being a spiritist. He was able to carry out occult exercises that prove that he had the skills that spiritists are thought to have; this without him being one of them.

Steiner is portrayed as a person who was persecuted undeservedly because his spiritual senses made him different from other people, which these could not accept. Being persecuted for such reasons automatically gave Steiner a martyr's crown.

Finally, Steiner is described as an exceptional scientist and a universal genius, who mastered science in its entirety, including the natural sciences. Characteristic of Steiner was that in him, science and religion were united.

\section{Conclusions}

My attempt to define what view of him the Anthroposophical writers of Rudolf Steiner's obituaries held, shows that they regarded him as a human being and not as a divine or semi-divine being. This is important when trying to classify what type of religious authority Rudolf Steiner represents.

In his work Einführung in die Religionsphänomenologie, Günter Lanczkowski uses the concept 'type of religious authority' - a concept he has borrowed from Joachim Wach-to categorise persons who are characterised by 'possessing religious authority among their fellow men and often also for later generations, which is based on personal or institutional charisma, a gift of grace that they have been endowed with' (Lanczkowski 1978: 84). Lanczkowski notes that the borders between the different types of religious authority that he operates with are shifting, and that in rare cases one and the same person can be classified as more than one type. He sees the Buddha as one such exception, whom he classifies as a mystic, a teacher and the founder of a religion. The types of religious authority that Lanczkowski defines in this context are the following: 'the sacred ruler', 'the anointed', 'the prophet', 'the mystic', 'the teacher', 'the founder of a religion', 'the reformer', 'the priest', 'the shaman', 'the hidden messiah', 'the guard of god', 'the martyr' and 'the holy' (Lanczkowski 1978: 84-107). The types of religious author- 
ity that have emerged in the obituaries of Steiner include 'the spiritual leader', 'the teacher', 'the founder of a religion', 'the occultist', 'the martyr' and 'the scientist and thinker'. Of these, 'the spiritual leader' and 'the scientist and thinker' do not occur among Lanczkowski's set of types, and neither does 'the occultist', but this type is very close to Lanczkowski's category of 'the mystic'. The fact that the typologies do not entirely match does not constitute a problem, since Lanczkowski's typology in no way claims that all types in each historic religion would be represented in it.

Based on my analysis of the source material, I regard the pair of terms 'founder of a religion-teacher' as the concept expressing the most essential elements of Steiner's religious authority. The term used in the above systematisation of the material, that is 'spiritual leader', is in its entirety implied in the combined term 'founder of a religion-teacher'. If this term is further supplemented with the term 'occultist', the image of Steiner's religious authority becomes more justified and complete.

The full description of this authority is thus encompassed in the terms 'founder of a religion-teacher' and 'occultist'. This leads to the presentation of the assumption that it is Steiner's authority which more than any other aspect explains the quick spread of the Anthroposophical Society. However, this assumption so far still waits to be confirmed. *

\section{References}

Beckh, $\mathbf{H}$.

1925 Rudolf Steiner in der Geschichte des lebendigen Wortes. Die ChristenFreiling, $R$. gemeinschaft 2 (2).

1925 Rudolf Steiner und die neue Frömmigkeit. Die Christengemeinschaft 2 (2).

\section{Karutz, R.}

1925a Rudolf Steiner. Goetheanum 4 (20).

1925b Rudolf Steiner. Goetheanum 4 (21).

Krauss.

1925 Zu Carl Albrecht Bernoullis Nekrolog auf Rudolf Steiner. Goetheanum 4 (21).

* The terms 'martyr' and 'scientist and thinker' are here judged to describe less central sides of Steiner's authority, and it is therefore not justified to include them in the description of Steiner's religious authority. 
Lanczkowski, G.

1978 Einführung in die Religionsphänomenologie. Darmstadt.

Picht, C. S.

1925 Eine Rudolf Steiner-Feier in Weimar. Goetheanum 4 (27).

Reinhart, $\mathrm{H}$.

1925 An der Bahre unseres treuen Freundes und geistigen Führers. Goetheanum 4 (15).

Rittelmeyer, $\mathrm{F}$.

1925 Rudolf Steiner als Eregnis in der Geschichte des Christentums. Die Christengemeinschaft 2 (2).

Spörri, G.

1925 Rudolf Steiner als Führer der Jugend zum Priestertum. Die Christengemeinschaft 2 (2).

Steffen, A.

1925a Dem Gottesfreund und Menschheitsführer Rudolf Steiner. Goetheanum 4 (19).

1925b Begegnungen mit Rudolf Steiner. Goetheanum 4 (19).

1925c Letzte Stunden bei Rudolf Steiner. Goetheanum 4 (15).

1925d Aus der Gedenkrede Albert Steffen. Goetheanum 4 (16).

Uehli, E.

1925 Erinnerungen an Rudolf Steiner. Goetheanum 4 (23). 